\title{
Panacea or diagnosis? Imaginaries of innovation and the 'MIT model' in three political cultures
}

Social Studies of Science

I-28

(C) The Author(s) 2017

Reprints and permissions: sagepub.co.uk/journalsPermissions.nav DOI: 10.1 |77/03063।27|7706।I0 journals.sagepub.com/home/sss

@SAGE

\section{Sebastian Pfotenhauer}

Munich Center for Technology in Society (MCTS) and TUM School of Management, Technical University of Munich, Munich, Germany; Institute for Data, Systems, and Society, Massachusetts Institute of Technology (MIT), Cambridge, MA, USA

\section{Sheila Jasanoff}

Program on Science, Technology \& Society, Harvard Kennedy School, Cambridge, MA, USA

\begin{abstract}
Innovation studies continue to struggle with an apparent disconnect between innovation's supposedly universal dynamics and a sense that policy frameworks and associated instruments of innovation are often ineffectual or even harmful when transported across regions or countries. Using a cross-country comparative analysis of three implementations of the 'MIT model' of innovation in the UK, Portugal and Singapore, we show how key features in the design, implementation and performance of the model cannot be explained as mere variations on an identical solution to the same underlying problem. We draw on the concept of sociotechnical imaginaries to show how implementations of the 'same' innovation model - and with it the notion of 'innovation' itself - are co-produced with locally specific diagnoses of a societal deficiency and equally specific understandings of acceptable remedies. Our analysis thus flips the conventional notion of 'best-practice transfer' on its head: Instead of asking 'how well' an innovation model has been implemented, we analyze the differences among the three importations to reveal the idiosyncratic ways in which each country imagines the purpose of innovation. We replace the notion of innovation as a 'panacea' - a universal fix for all social woes - with that of innovationas-diagnosis in which a particular 'cure' is 'prescribed' for a 'diagnosed' societal 'pathology,' which may in turn trigger 'reactions' within the receiving body. This approach offers new possibilities for theorizing how and where culture matters in innovation policy. It suggests that the 'successes'
\end{abstract}

\section{Correspondence:}

Sebastian Pfotenhauer, Munich Center for Technology in Society (MCTS), TUM School of Management, Technical University of Munich, Augustenstraße 46 (Rückgebäude), 80333 München, Germany.

Email: sebastian.pfotenhauer@tum.de 
and 'failures' of innovation models are not a matter of how well societies are able to implement a sound, universal model, but more about how effectively they articulate their imaginaries of innovation and tailor their strategies accordingly.

\section{Keywords}

best practice transfer, co-production, innovation model, MIT, sociotechnical imaginaries

\section{Innovation, national political cultures and the standardization of practice}

Innovation has become a leitmotif of policy-making and institution-building around the globe. Hardly a week passes without some government announcing an 'innovation strategy' for a city, region or country, or without some institution branding itself a driver of innovation. The bumper year 2014 is illustrative. In July of that year, for example, the US government published a proposed new 'Strategy for American Innovation' (Office of Science and Technology Policy (OSTP), 2014). That same month, leaders of the African Union adopted the 'Science, Technology and Innovation Strategy for Africa' (African Union, 2014); the EU held a country workshop on Research and Innovation Strategy for Smart Specialization (European Commission, 2014); the British Royal Society and Academies announced their joint submission of a contribution to the UK's forthcoming Science and Innovation Strategy (Royal Society, 2014); the province of Alberta, Canada, launched a new Innovation Council to lead the province's innovation strategy (Alberta Government, 2014); the fledgling innovation agency of New Zealand, Callaghan Innovation, announced five strategic initiatives as part of its first 4-year roadmap (Callaghan Innovation, 2014); the City of Chicago approved its first community development plan aimed at creating an innovation district (Elejalde-Ruiz, 2014); and Tufts University announced the launch of the new Tufts Institute for Innovation as part of its strategy for 'Tufts: The next 10 years' (Tufts University, 2014).

Innovation has become a go-to answer, a panacea that carries the promise of curing socioeconomic ailments almost irrespective of what these ailments are or how they have arisen. Indeed, it has become virtually impossible to talk about economic development or social progress in terms that do not invoke, explicitly or implicitly, the need for innovation. Innovation is designated as the key to a better future, promising economic growth and competitiveness, but also solutions to persistent social challenges such as energy, the environment, health, or aging (Fagerberg et al., 2006; Organization for Economic Cooperation and Development (OECD), 2010). Accordingly, innovation appears as a central agenda item in policy domains ranging from research to development, education, immigration, environment, health and aging, employment, taxation, industrial policy and risk governance, among others. Some have argued that 'innovation policy' has effectively absorbed many other policy domains, whether because of its own virtues (Fagerberg et al., 2013; Lundvall et al., 2010) or as the result of purposefully 'staking the claims for a new disciplinary tribe' (Godin, 2014). Indeed, it seems as if all governmental functions must cater to a discourse of innovation in order to appear economically defensible, politically legitimate and suited to this historical moment. 
With its rise to prominence as a policy goal, innovation has become inextricably associated with abstract innovation models that, supported by a wealth of academic literature, aim to explain scientifically what innovation is, what it is for, how it works and who needs to be involved. Despite its increasing sophistication, this literature remains wedded to an implicit understanding that innovation is universally desirable and follows a quasi-universal pathway, engaging an array of components, actors, material conditions and practices arranged in different but complementary ways. US science impresario Vannevar Bush's (1945) manifesto Science, the Endless Frontier is often taken as the starting point for this way of thinking, in which innovation occurs through a linear pipeline from publicly funded basic research to industry-funded applied research and, eventually, commercialization - though Godin (2006) has shown that this origin story is a retrospective ascription that is historically untrue and linked to the 'invention' of stages of innovation. Many subsequent refinements were framed in response to the perceived shortcomings of the linear model, for example by insisting on demand pull as a better explanation than science push (Godin and Lane, 2013) or by suggesting that the relationship between science and the market is better captured through complex chain links between identifying and catering to market demand and producing and utilizing knowledge (Kline and Rosenberg, 1986). Since the early 1990s, systemic models of innovation have framed innovation as a synergistic interplay of different actors and institutions that serve complementary functions in a complex, distributed process that includes research, development, education, translation, financing and regulation, among others (Lundvall, 1992; Nelson, 1993; OECD, 1997). Here, countries are imagined as featuring their own idiosyncratic national system layouts, and bottlenecks in any part of the system are thought to undermine the system's overall performance (Kuhlmann et al., 2012). Similar arguments have been made for regional or sectoral innovation systems (Braczyk et al., 2004; Malerba, 2005). Innovation has also been conceptualized as a triple (or even quadruple) helix of university-industry-government(-society) interactions that create hybrid innovation spaces and thrive on the erosion of boundaries between the formerly distinct spheres of academia and the private and public sectors (Etzkowitz, 2008). ${ }^{1}$

More recently, attention in innovation studies has tilted noticeably toward what one might call 'models of practice'. Here, the move is toward teasing apart, and if possible emulating, the key things that successful innovative institutions and regions $d o$, as evidenced by the global popularity of the 'Silicon Valley model' or the 'MIT model' (Bresnahan and Gambardella, 2004; Casper, 2007; Etzkowitz, 2002; Kenney, 2000; Lee et al., 2000). Indeed, government and company delegations are constantly being dispatched to the Bay Area to see for themselves and report back on Silicon Valley's secret sauce so that others, too, can use it as a seasoning. Models, in this understanding, are no longer structural abstractions expressed through metaphors such as 'pipeline' or 'triple helix', but are understood instead as role models manifest in the successful practices of real-world institutions or regions. This 'practice turn' in innovation policy is indicative of two broader trends (Pfotenhauer and Jasanoff, 2017). On the one hand, innovation is no longer purely (or even mainly) seen as an analyst's category, articulated by academics to theorize technological change and economic growth. Instead, it has become a practitioner's category, with increasing numbers of actors engaged in doing, implementing or fostering innovation. On the other hand, the practice turn is consistent with 
a broader shift towards competitive benchmarking as a modus operandi in public policy, where progress toward achieving the goals of innovation is typically measured by reducing various 'performance gaps' (De Ferranti et al., 2003; OECD, 2010). While benchmarking is generally applied as a tool for organizational and policy learning (Papaioannou et al., 2006), it also serves as a means for policy-makers to exercise agency by asserting that innovation is something whose elements can be identified, standardized, packaged and shipped across borders. It thus hedges risks for policy decisions and grants legitimacy by allowing policy-makers to offer public assessments of their practices in terms of relative success in meeting widely agreed upon indicators of effectiveness (Pfotenhauer, in press).

Although the practices of innovation are supposedly well-understood and translatable, the transfer of innovation models - both abstract models and models of practice has consistently disappointed the immense expectations pegged to them, be it at the institutional, regional or national level. An increasing number of policy scholars and practitioners, especially from developing countries, find models such as 'innovation systems' or 'triple helices' downright inapplicable in light of the profoundly different institutional and political contexts across rich and poor countries (Arocena and Sutz, 2000; Cassiolato and Vitorino, 2011; Chaminade and Padilla Pérez, 2014; Dutrénit and Puchet, 2017; Kuhlmann and Ordóñez-Matamoros, 2017). Efforts to reproduce such iconic formations as Silicon Valley or MIT in new places have regularly led to frustration, with the import seldom living up to the promise of the originals. This is consistent with a broader history of policy imports for economic development, such as various forms of market liberalization emanating from the West into the rest of the world since the $1980 \mathrm{~s}$, that have failed to make 'catching-up' countries converge at the innovation frontier - an idea that is now increasingly being dismissed as overly optimistic and counterproductive (Amsden, 2007; Barro and Sala-i-Martin, 1992; Islam, 2003). In contrast, a range of studies speak to the persistently unequal geography of innovation (Acemoglu et al., 2002; Feldman, 1994), where spikes, not flatness, are the rule (Florida, 2005).

Surprisingly, failure to implement an innovation model successfully is rarely attributed to the models themselves. Instead, it is commonly held that cultural differences subsumed under the heading of 'context' - prevent the model from functioning well. While it has become commonplace to assert that 'culture matters' for innovation, less has been done to show why, when and how it matters. ${ }^{2}$ Rather, culture is the label applied to an exogenous set of constraints that are thought to undermine or explain the performance of an otherwise sound innovation model. Alternative, culturally distinct conceptions of innovation remain outside the mainstream innovation discourse, just as the majority of countries remain outside the 'innovation club'.

In this paper, we offer an approach that does not artificially separate the dynamics of innovation from its cultural context, and hence avoids essentializing either innovation or culture. Instead, we use a co-productionist perspective that allows us to consider what an innovation $i s$ and the social orders in which this knowledge is brought to bear as coevolving with one another. More specifically, we suggest that an imported innovation model should be understood as part of a collectively held imaginary of sociotechnical progress that accompanies a complementary diagnosis of a deficiency in the receiving environment. Both the 'diagnosis' and the imagined 'cure', in the form of the imported 
model, are shaped by and reinforce pre-existing visions of desirable and undesirable futures in a given society. Empirically, we analyze such imaginaries of innovation through a cross-country comparison of three implementations of a single innovation practice - the 'MIT model' - in the UK, Portugal and Singapore, all carried out with the active engagement of MIT itself. ${ }^{3}$ These three implementations of the 'MIT model' look very different. This is not, we argue, because a well-defined, preexisting 'MIT model' had to be reconciled with variations in local culture, but because the three societies diverged in their expectations of the role an imported 'MIT' could and should play in their innovation strategies, and thus imagined fundamentally different things under the rubrics of both 'MIT' and 'innovation'. Our analysis thus flips the conventional wisdom about 'best-practice transfers' on its head: Instead of asking how well an innovation model has been adopted, we look at differences in the imagination, implementation and uptake of the model as windows onto unique social, political and cultural determinants that underwrite innovation policy in each of our comparison countries.

In identifying culturally specific imaginaries of innovation, we find it productive to turn to medical metaphors of illness, diagnosis, reaction and cure. What governments and institutions envision under the label 'innovation', we show, depends primarily on the ways in which they perceive their own weaknesses - whether sluggish growth, waning global influence, ossified institutions, complacent populations, human resource constraints or lack of a national vision - which we capture through the term 'diagnosis'. The medical lens allows us to deconstruct the widespread rhetoric of innovation as a panacea that promises to fix societal woes almost independently of where these woes occur, and that can be incorporated through a standardized therapeutic model - in this case the 'best practice' model of MIT. The panacea rhetoric obscures how the imagined availability of a cure encourages the framing of a self-diagnosis. We show, by contrast, that the nature of the 'disease' matters to the local conception of innovation, and that the presumed universality of innovation breaks down in reality into a host of disparate visions, objectives, activities, and cultural practices. What is more, we demonstrate how the incorporation of a supposedly standard innovation model triggers complex and varied reactions, including outright rejection, within the body being treated.

\section{Imaginaries of innovation}

The link between imagination and innovation has received increasing attention in STS and policy research. Going beyond the commonplace desideratum of the visionary ingenuity of the innovator, STS research has emphasized how innovation also conjures up images of undesirable futures and fear, for example in the form of runaway technologies or moral erosion (Jasanoff, 2005b; Sturken et al., 2004). Innovation forces us to live with and anticipate risks and unavoidable consequences, leading to new uncertainties and social fragility (Barben et al., 2007; Beck, 1992; Guston, 2008). Nowotny (2006) argues that innovation is but the latest declension of the promise of modernity itself, with its deep belief in progress, but inflected by the uncertainties, ambiguities and disappointments of post-modernity. Another branch of STS research has explored the performative function of imagination in relation to technologies through a sociology of expectations. Borup et al. (2006) contend that expectations 'guide activities, provide structure and 
legitimation, attract interest and foster investments', and therefore may become 'wishful enactments of a desired future' that may lead to 'certain material and social path dependencies (lock-in or irreversibility) becoming the basis for future envisioning, a predisciplining of the imagination through the legacy of former expectations'.

While the link between innovation and imagination has been studied at the level of individuals and technologies, little research exists that explicitly connects innovation to collective self-imagination - and hence explicitly to the level of national innovation policies. Yet, as evidenced by the examples cited at the outset of this article, innovation has long since risen to that level of collective meaning-making, mobilizing shared national visions and a joint sense of belonging. Imaginaries of innovation can be seen, then, as epistemic and political resources for defining a community that shares a common (and hopefully better) sociotechnical future, and that is on its way to attaining it through innovation. Imaginaries provide a thread of continuity and stability by extending existing frames of reference from the past into the future, thus mitigating the unknown through what is known and taming the disruptive quality of innovation through what is imaginable and permissible in a given social, political, and historical context. It is precisely this shared sense of belonging that holds together states and institutions as imagined communities over time (Anderson, 1991), allowing members to access shared forms of meaning-making and interpretations of social reality. Our contention, going beyond Anderson, is that these acts of collective sense-making today inevitably involve the enrollment of science and technology into the collective project.

Our analysis is grounded in the co-productionist strand of STS research that explores how science and social order are mutually constitutive (Jasanoff, 2004; Latour, 1993), as well as traditions in interpretive policy analysis (Dryzek, 1990; Schön and Rein, 1995; Stone, 2001). We regard innovation as a prime site for the operation of sociotechnical imaginaries (STIs), defined as 'collectively held, institutionally stabilized, and publicly performed visions of desirable futures, animated by shared understandings of forms of social life and social order attainable through, and supportive of, advances in science and technology' (Jasanoff, 2001; Jasanoff and Kim, 2015). Significantly departing from earlier work on imaginaries by Anderson (1991), Appadurai (1996), and Taylor (2003), sociotechnical imaginaries seek to account for both 'the growing recognition that the capacity to imagine futures is a crucial constitutive element in social and political life' and the lack of adequate theoretical resources to deal with scientific and technological change (Jasanoff and Kim, 2009). Such imaginaries are particularly germane to the study of big technology initiatives as sites of contemporary state-making and societal reconfiguration, explicating why the norms and practices surrounding seemingly identical technologies (such as nuclear power) differ substantially across countries. STIs are wellsuited to characterize relatively stable, relatively high-level societal commitments and their effects on science and technology; they help us trace and explain why attempted transfers of sociotechnical systemic arrangements across cultures and jurisdictional borders so often result in divergent social and political outcomes. ${ }^{4}$

Charting a desirable future, we further posit, inevitably presupposes an undesirable present as the backdrop. As we will see, innovation policy is routinely constructed as addressing a collectively felt and publicly diagnosed deficit. Such diagnoses are necessarily normative: They entail value judgments about 
what constitutes the public good, which publics should be served by investments in science and technology, who should participate in steering science and by what means, and how should controversies be resolved about the pace or direction of research and development. (Jasanoff and Kim, 2009)

It is in light of this communal deficit construction that public policy can plausibly call for more entrepreneurial universities, a more aggressively risk-taking attitude or a new ideal type of university graduate (the 'engineer-entrepreneur'). Yet, as we shall see, the precise meanings projected onto these terms remain unintelligible without accessing the political and cultural foundations on which they are constructed.

By studying STIs in a comparative manner, we also build on STS research that has investigated, among other things, national 'styles' of regulation and policy-making (Brickman et al., 1985; Kelman and Wilson, 1981), how innovation links up with different 'cultures of technology' (Nowotny, 2006), how standardization and universality are always locally achieved through the social work surrounding scripts and protocols (Timmermans and Berg, 1997), and how societies address technological challenges through unique relationships between knowledge-making, policy-making, and public sense-making (Jasanoff, 2005b).

\section{Implementing the MIT model: Three case studies}

\section{The Cambridge MIT Institute (CMI): Rejuvenating UK industry}

In July 1998, a small number of MIT faculty and administrators met with Gordon Brown, then Chancellor of the British Exchequer, to explore the possibility of a large innovation partnership between MIT and the UK. Increasingly concerned about the decline in British economic leadership and vitality, and a sense that this waning might in part be due to the ossification of British universities, which despite the 'high quality of academic science in the UK' exhibited a 'historically weak commercial awareness' (Department of Trade and Industry (DTI), 2001), Brown jumped at a rumor that MIT was considering a partnership with Ireland. A regular Cape Cod vacationer, Brown was impressed by what he saw as MIT's role in transforming the manufacturing economy and spurring growth for an entire region, and he requested an ad hoc meeting while visiting the United States. The Cambridge-MIT Institute (CMI) was launched in November 1999 to bring this transformative potential into a 'momentous [collaboration] for the future of entrepreneurship in Britain as a whole', as Alec Broers, ViceChancellor of Cambridge put it (University of Cambridge, 1999a). Almost from its launch, however, CMI faced a tension. On the one hand, CMI was imagined as a 'joint venture' between universities of equal standing (CMI, 2008) - an 'Institute', rather than a program or partnership, 'bringing together two of the world's great universities to build on the complementary strengths of each' (CMI, 2005). On the other, CMI was imagined as deeply asymmetric - with the foreign partner providing a much-needed shot in the arm for an ailing economy and a targeted injection of innovation practices into the very heart of an aging British university system. CMI sought to implement 'an Anglicized version of the "MIT approach", and all that has delivered in terms of economic dynamism to Boston and the regional economy of New England' (CMI, 2008); it 
was to foster the 'adoption in the UK of practices and associated skills available in MIT, reflecting its highly entrepreneurial culture, [which are] likely to address some perceived deficiencies in the UK innovation system' (Simmonds et al., 2009). Announcing CMI's formation, Vice-Chancellor Broers expressed both pride and anxiety, emphasizing Cambridge's commitment 'to seeking partnerships with the world leaders to ensure that we remain in the top rank of the world's universities' (University of Cambridge, 1999b); industry leaders involved in the partnership, such as BP CEO John Browne, likewise saw it as a sign that 'confirms the status of Cambridge as one of the world's great universities' (University of Cambridge, 1999a).

The timing for the partnership was also problematic. CMI was conceived amidst considerable public turmoil about the future and finances of the British university system (Dearing, 1998; Deem et al., 2007; DTI, 2001). The proposal to pour the equivalent of 100 million dollars into Britain's richest university and an even richer American counterpart was politically uncomfortable at a time when public financing of higher education was in disarray, tuition sharply on the rise, ideas of new public management sweeping across the university sector, and the traditional elitism of the British university system under attack from public discussions about access and equity. Indeed, for similar reasons, Brown - a Labour member and avowed anti-elitist - had originally proposed to create an entirely new institution ('an MIT in the UK', as one MIT faculty remembers), which MIT rejected, and then temporarily set his mind on his own alma mater, the Scottish University of Edinburgh, to partake in a collaboration. This intention, however, quickly gave way to the criterion of equal standing, which also outweighed practical considerations whether to partner with an engineering school, like Imperial College. Thus, an MIT faculty remembers, 'it basically came down to Cambridge or Oxford'. As in earlier times, the esteemed University of Cambridge - home to Newton, Bacon, Maxwell, Darwin, Rutherford and many Nobel Prize winners, prime ministers and royals - was chosen to lead a country at risk of falling behind out of what was perceived as a national crisis. From Cambridge, it was envisioned, these positive effects would radiate outwards into the entire British university landscape, facilitated by linkages between Cambridge and other universities that did not enjoy direct ties with MIT.

Reactions within the Cambridge academic community ranged from enthusiasm to skepticism to outright indignation. An MIT participant recalls how the appearance of MIT's first emissaries to Cambridge ('non-Brits with an engineering background [who] could not be less Cambridgey') led to responses such as: 'Who does MIT think it is, parachuting in and telling the University of Cambridge what to do?' For many, the working assumption was that Cambridge already excelled in everything it did. Excelling in innovation was not generally perceived as necessary for the standing of the university but rather aroused concern about the impurity of commercially driven research. CMI's reception was not helped by the fact that no one at Cambridge had been involved in the planning and negotiations. Over a year and a half, the plan was hatched by the Treasury 'totally in secret', a senior administrator at MIT remembers. '[N]o one knew a word about this until two weeks before the contract was signed. ... [Brown] was concerned that once word got out it would be killed.'

Given both the critical timing and the lack of involvement, CMI's mission of rejuvenating Cambridge got off to a rough start. 'Changing the Cambridge DNA [was] really tough', one professor recalled. 
[T]aking off the shelf a number of things ... and adding a few new things - that's the MIT model - is that much harder to do in Cambridge [with] the incrustation of 800 years ... So we spent a lot of time fighting with senior people in departments ... trying to persuade them to change the way they do things so that we could do what we were supposed to do for CMI.

Indeed, for many of the suggested activities, there did not seem to be an obvious institutional home. Six professional practice master's programs established by CMI, designed to cross disciplinary boundaries between science, engineering, management and policy and modeled after existing MIT programs, ended up being partly hosted and run through the Judge Business School, which created barriers for collaboration with engineering and science. What is more, Cambridge refused to touch its $\mathrm{PhD}$ programs to promote innovation: Industrially oriented $\mathrm{PhDs}$, well known at MIT and suggested for the partnership, were not up for debate. At Cambridge, 'you either did science and engineering technology, [which] tended to be much more academically oriented, or you did an MBA', a Cambridge faculty member explained. At the same time, visiting MIT undergraduate exchange students tended to underperform academically vis-à-vis both their Cambridge peers and their performance at home, which played into the hands of some of the critics. Cambridge faculty saw the MIT students as over-programmed, driven by tests, and lacking the independence to use Cambridge's resources fully. MIT faculty attributed the difficulties mainly to adjustment problems to the Cambridge tutoring system. One remembered that he and his colleagues constantly had to make sure that

the tutors and some of the faculty ... took these kids seriously. You know, I said these are the best in the US, ... don't treat them like they're some kids that are coming over and ... taking English as a second language or something. ${ }^{5}$

While the opportunity to collaborate was welcomed by many and joint research did indeed produce widely noted results (Simmonds et al., 2009), most research remained centered on preexisting faculty interests and in fact 'stopped pretty dead ... once the money stopped', a Cambridge professor remembers. Having undergone considerable budget cuts in science funding, many Cambridge faculty viewed CMI, in the words of one MIT participant, as a 'sort of a golden pot of money that's coming to me with no commitment to worry about. They didn't care about whether CMI did well or poorly, whether the government was right or wrong.'

MIT faculty, for their part, had difficulties adjusting to the culture of accountability in the UK, which they considered 'excessive' and 'counterproductive'. Hinting at MIT's more free-wheeling self-image, one senior MIT faculty member noted

These people were asking us questions about input and output variables, in terms of we put this amount of money in, [now] tell us what the outputs are going to be one year, two years, five years out. ... That's not, at least in 1999, the way that MIT works and thinks... You know, we'll write a proposal. It's going to be open-ended. Give us a lump of money, and at the end of that, we will deliver [something of value]. Trust us, because you know our track record.

In practice, CMI's role became one of minimal invasiveness: creating add-on activities that could come on top of, but would not substantially interfere with, already existing 
research and education - nor fundamentally alter the way in which the university operated and how it related to other parts of society. In classical innovation policy terms, CMI conceived of itself as establishing the missing rear-end of the innovation pipeline to complement an existing strong front end, embodied by Cambridge's traditional excellence in education and research. Innovation was imagined as a downstream activity of existing research, not, as Brown had hoped, something fundamentally new or systemically different.

Thus, Gordon Brown's vision of transforming the UK by injecting MIT's innovative DNA into Britain's most iconic university collided with the self-images of two institutions that differed with regard to their understanding of what innovation is and (whether) and how it should be implemented. ${ }^{6}$ Notably, MIT faculty frequently emphasized that they generally did not consider innovation and entrepreneurship as mere add-ons to a classical research university. Rather, these were seen as integral parts of MIT's institutional identity, pervasive throughout education, research, support infrastructure and outward orientation. In contrast, wide swaths of the Cambridge faculty did not consider their university to need an innovation boost, were struggling with cuts in regular research funding and perhaps deep down found an innovation add-on tantamount to corrupting the university's excellence in pure research. The final report of CMI still found it necessary to emphasize that 'bibliometrics do not suggest that the CMI philosophy had compromised research quality'. This is not to say that CMI (and Cambridge more generally) did not have its own innovation success stories. For instance, the 'Silent Aircraft Initiative' was a widely celebrated example of successful university-industry collaboration with Rolls Royce. Yet, 'it was not nearly as much on startups as it was on doing research and then getting companies to pick up the research', a faculty participant remembers. Hence, CMI was unable to induce major structural or institutional changes and, in the eyes of many, ultimately fell short of its transformative potential. One Cambridge faculty member likened CMI to 'a little burr which gets into the skin, right? You know, it's kind of there, it's irritating. But after a while, the skin grows over it.'

\section{The MIT Portugal Program (MPP): Overcoming self-inflicted disability}

In early 2006, at the peak of the European reform fervor surrounding the 'Lisbon Strategy' and the 'Bologna Process' - the former intended to 'step up the process of structural reform for competitiveness and innovation', the latter to create a single European higher education and research space (European Council, 2000; Keeling, 2006) - a Portuguese delegation visited several US universities to discuss the possibility of large-scale partnerships with Portugal's leading universities. The delegation included Carlos Zorrinho, national coordinator of the Lisbon Strategy, and Manuel Heitor, a prolific innovation policy scholar and Secretary of State of Science, Technology, and Higher Education. As an external examiner of the CMI initiative, Heitor was well aware of its difficulties; yet, he had also argued that a small peripheral country like Portugal needed to participate in international knowledge networks, bold institutional change, and an influx of ideas and human resources in order to succeed (Conceição et al., 2003; Heitor and Bravo, 2010; Heitor and Horta, 2011). A six-month feasibility study, involving 
faculty and institutional leadership from a range of Portuguese institutions, led to the launch, in August 2006, of the MIT Portugal Program (MPP) - the first of five international agreements that also included Carnegie Mellon, University of Texas at Austin, Harvard Medical School, and the German Fraunhofer Society). MPP was cast as a 'national initiative involving seven Portuguese universities and 14 research centers' that would 'leverage MIT's experience in [science, technology, and higher education] to strengthen the country's knowledge base through an investment in human capital and institution building' (Massachusetts Institute of Technology (MIT), 2005).

MPP's more open and transparent starting point, as compared to CMI's, speaks to the different political and institutional setting of Portugal. In terms of its historical lineage, Portugal's university system compares favorably with the UK's, with the University of Coimbra dating back as far as 1290. Yet, Portugal's modern higher education landscape suffered from a half-century of dictatorship until a military coup cum leftist revolution brought about democracy in 1974. Universities struggled with the heritage of an elitist, politicized system, a striking absence of scientific and technological capacity due to farranging deindustrialization under the Salazar regime, and low public trust in national institutions. After 1974, universities experienced a leveling of inequality and a push for democratization and openness: Research funds were distributed more or less equitably throughout the system, inhibiting the emergence of strong national research universities committed to newer discourses of excellence and international competition (Heitor and Horta, 2011). Similarly, a process of massification, setting in slowly after 1974, eventually increased the student population ten-fold (to about 400,000) by the year 2000. This rapid expansion in conjunction with a considerable brain drain created a 'dual society', in which a young, highly educated cohort co-exists with a majority workforce with little education and low scientific literacy (Heitor and Bravo, 2010).

The experience of national trauma - post-colonial downfall, societal fracture, delayed recovery - lives on in Portugal's self-image as a 'peripheral' and 'catching-up' country, aggravated by 'late integration' into the European Union and a 'bumpy road of economic convergence' (Aiginger, 2004; Lains, 2003; Veugelers and Mrak, 2009). This narrative of backwardness goes hand-in-hand with an imaginary of self-inflicted wounds. The Portuguese sociologist De Sousa Santos (2009) suggests that the tangible remnants of past glory and subsequent decline are regularly drawn upon to as 'historical conditions that explain the deficiencies of the present'. Portugal diagnoses its internal challenges 'as backwardness vis-à-vis the present of the more developed countries', from which the distance is 'mainly due to internal causes'.

This dual imaginary of backwardness and self-infliction provides an entry point for understanding innovation policy in Portugal. Innovation is seen as an aid to making up for a 'late-awakening', in the words of Secretary Heitor (Heitor and Horta, 2011). It explains why the government embraced a complete break with existing institutional structures and traditions, and why the aid had to come from the outside in the form of MPP. For example, MPP introduced seven American-style graduate programs - four PhDs with integrated Master's and three professional Master's programs - to an otherwise traditional continental European education environment. All courses were offered in English, many of them co-taught by Portuguese and MIT faculty, some of the programs designed entirely as a sequence of fast-rotating two-week modules spread out 
throughout the country, and degrees were jointly awarded by several Portuguese universities - a complete novelty. Portuguese junior faculty were encouraged to visit MIT and audit classes on innovation to adapt them for a Portuguese context (for example, more than 20 Portuguese faculty audited MIT's popular 'innovation teams' course, in which students develop business plans for emerging biotech research in cooperation with company partners) (Pfotenhauer et al., 2013). As a result, 'students are a lot more involved in entrepreneurship and innovation', a faculty member suggests, 'which is totally absent from other PhD programs'. MPP was purposefully leveraged to attract foreign students to Portugal - marking a reversal from a 'sending' country to a 'receiving' country. Furthermore, research focused at least in part on domains in which Portugal had no significant pre-existing expertise, for example stem cell research, whereby the MIT connection was leveraged to jumpstart new initiatives.

Portugal's social and institutional history also explains why MPP built on a much broader institutional base. In line with the post-revolution commitment to equity, MPP included a consortium of seven Portuguese universities. Yet even the consortium structure was not entirely able to circumvent public criticism against 'elitism' and 'non-transparency'. Three years into the Program, MPP had to redesign its internal organization around publicly administered, open calls, which in principle would have allowed all Portuguese universities to participate. The more open structure did in fact lead to the self-application by, and later integration of, a research group at one university that initially had not been part of the program (Pfotenhauer et al., 2013). The consortium setup further addressed a longstanding pattern of inter-institutional competitiveness and insulation - literally 'forcing' people to work together, as one MPP participant remembers. A Portuguese senior government official described the role of MIT as a 'glue' that incentivized Portuguese universities to work together through the opportunity to work jointly with MIT.

Together, the imaginaries of backwardness and self-infliction explain why innovation in Portugal was seen as part of a process that needed external assistance - a kind of prosthetics to make up for the fractures of the past. Innovation in Portugal was thus framed not as minimally invasive, but as a decisive break with this past and a radical overhaul of inherited structures and constraints. It was a process that required closing ranks with leading research nations by importing people, practices, and programs. MPP followed a decentralized, anti-elitist approach that sought to build strength through national cooperation while unleashing institutional change from within. In 2012, the government of Portugal renewed its commitment to MPP, despite a continuing economic crisis and multiple changes in government, indicating strong, high-level, national buy-in.

\section{MIT-Singapore: Health care and performance of a global city}

In early 2008, a group of senior MIT faculty with long-standing ties to Singapore requested a meeting with Tony Tan, head of the National Research Foundation, former Minister of Education, and later president, to discuss the Singapore-MIT Alliance (SMA), an ongoing partnership in its 9th year designed by Tan and former MIT provost Bob Brown. According to one person present at the meeting, Tan, widely credited as the chief architect of Singapore's current higher education system, indicated that 'the most 
important thing Singapore was going to do in education over the next decade or two was to create a new university', and that they were looking for an international partner for this endeavor. Despite the implied invitation, it was clear that MIT would not be the only potential candidate in this process. Singapore had recently undergone a radical opening of its higher education and research system to foreign institutions, launching the Duke-NUS Graduate Medical School, the Yale-NUS College, the Rutgers Business School Asia-Pacific, the Johns Hopkins Division of Biomedical Sciences, the NYU Tisch School of Arts, INSEAD Asia, and ten foreign-led research centers at the Campus for Research Excellence and Technological Enterprise (CREATE). Yet it was MIT that in early 2010 signed an agreement to jointly establish the Singapore University of Technology and Design (SUTD), with aspirations 'no less' than MIT itself to 'create a new type of technologically grounded leader' with 'the passion to literally change the world' (SUTD, 2012).

To achieve this, the Singaporean government felt the need for a decisive break with the established research and education landscape - 'something different from the existing institutions', according to Prime Minister Lee Hsien Loong - and it turned to MIT to effect this break. This move resonated strongly with Singapore's self-prescribed upgrade 'from efficiency-driven growth to innovation-driven growth' (Tan and Phang, 2005), and the self-diagnosis that the key factor hampering innovation was a lack of creativity, not engineering capability (Remaking Singapore Committee, 2003). A small, elite university outside the behemoth state universities NUS and NTU, SUTD emphasized creativity, design, and systems thinking as a counterpoint to Singapore's traditionally highly technical approach to engineering education; it was structured around cohort-based rather than lecture-based teaching, adopting many elements of what MIT faculty saw as the foundation of innovation at the undergraduate level. ${ }^{7}$ In particular, SUTD's curriculum reflects much of the latest thinking at MIT on educational best practices as expressed by an MIT internal task force (the 'Silbey Committee') and a previous report by the MIT Engineering Council ('From useful abstractions to useful design') on how MIT ought to restructure its own undergraduate education.

SUTD was not the first time that Singapore had turned to MIT to boost its innovation performance: The first major agreement between Singapore and MIT, the SingaporeMIT Alliance (SMA), was launched in 1999 primarily as an educational collaboration to 'develop talented human capital for Singapore's industries, universities, and research establishments' and 'attract and retain the very best engineering and life sciences graduate students and researchers from across Asia' (SMA, 2005). SMA introduced several new research-intensive graduate programs with strong application orientation and interdisciplinary curricula to the system, modeled after MIT practice and using a variety of distance-learning tools (including video lectures, student mobility periods to MIT, and a dual degree option). SMA speaks to a notion of innovation that stands in a direct lineage with Singapore's development-through-engineering paradigm and the outsized role of technical education in it (Huff, 1995; Keen Meng, 2010; Wong, 1995).

Based on the positive experience with SMA, in 2003 MIT and Singapore agreed to extend the partnerships to a second phase (SMA-2), which added greater emphasis on collaborative teaching and research by raising the residency requirements for MIT faculty in Singapore. Departing from SMA and its focus on classical engineering 
domains such as computer science, micro- and nanosystems, and manufacturing, SMA-2 moved heavily into the biological sciences, mirroring Singapore's broader effort to establish the life sciences as an innovative industry (Chuan Poh, 2010) and a shift in self-image from 'intelligent island to biopolis' after 2000 (Clancey, 2012). This move also echoed similar trends at MIT and in the Boston region, on which Singapore's leadership kept a close eye.

In 2006, MIT and Singapore signed yet another agreement - the Singapore MIT Alliance for Research and Technology (SMART) - which changed the principal focus from innovation through imported education to innovation through imported research, and elevated collaboration efforts from the programmatic to the institutionalized level. SMART was in effect a local research operation run by MIT and the first of a whole array of international research centers in the brand-new CREATE campus, which besides MIT also included ETH Zurich, TU Munich, Cambridge, and UC Berkeley, among others. CREATE's mission was to attract world-class foreign researchers to conduct research on Singaporean priority areas in Singapore. Innovation at SMART was envisioned as something done by MIT faculty, in their own lab environment, with MIT-type innovation support - but in Singapore. According to a senior MIT administrator, SMART functions as an 'MIT research lab 10,000 miles away'. Contrary to SMA, SMART focused on long-term residency: MIT faculty are expected to spend a total of one year out of a fiveyear engagement in residence in Singapore, with at least one consecutive stay of six months. In exchange, faculty receive considerable research funding, their own local laboratories and research staff, and support for local collaborative projects. Moreover, a translational unit was established (the SMART Innovation Centre) modeled after MIT's Deshpande Center, to help resident SMART faculty shepherd research into commercialization with the help of seed grants and coaching. SMART reflects a model in which Singapore sought to enhance its innovation performance by literally implanting MIT research, considered second to none, into the local research system. It was based on a mindset that Singapore was unwilling 'to wait until it's grown [a domestic research talent pool] before we can do significant research, so it had to have international talent at the same time', according to a senior manager at CREATE.

The triple generational shift SMA - SMA-2 - SMART - SUTD speaks to an imaginary of innovation through constant adaptation: The modus operandi here is akin to a therapy of physical enhancement where ever-new additions are sought to ensure and augment a healthy, optimally performing metabolism. MIT was brought in multiple times to supplant seemingly outdated versions of innovation that MIT itself had previously helped shape and consolidate, all of which sought to do 'something different'. A senior leader at SUTD noted that the latest partnerships

never would have happened without the previous relationships. ... There has been this increasing level of comfort with each other, ... and increasing understanding, and increasing alignments on high, very high levels of objectives in terms of pursuing knowledge, research, and education, and innovation.

In repeatedly re-diagnosing its deficit, Singapore sought to incorporate the latest insights and stimulants from the outside whenever they became available: interdisciplinary 
education, the foundations of a life science cluster, world-class research manpower, institutional frameworks for commercialization, undergraduate creativity. This approach treats the MIT model as disaggregable into disparate functions - like individual enhancement routines addressing different parts of the body, notably separating education from research, institutional change from institution-building and undergraduate from graduate education, among others. This is consistent with the highly technocratic, style of planned system-wide governance and overall pragmatic policy approach of Singapore's decades-long governing party, the People's Action Party (Huff, 1995).

The imaginary of enhancement and adaptation, furthermore, resonates strongly with a fear of losing autonomy that runs through all of Singapore's policies. Politically, Singapore has been dominated by worries about independence ever since the city-state's 1963 independence and a brief, turbulent merger with Malaysia from 1963 to 1965. The repeated public performance of a constantly looming security threat helped build a political identity around an unwavering agenda of military research and technology-based economic development (Perry et al., 1997). Economically, due to its lack of a hinterland, Singapore had to focus early on international trade, technology-based development, and integration into a global economic network, so that 'size would eventually become less important as [Singapore] became increasingly associated with a series of equally vibrant economic and technological centers, ... and Singapore could make up for its traditional disadvantages of size through such newly forged alliances' (Choon, 2004). Advancing the notion of an essentially 'global city,' Singapore advocated an image as a 'a new form of human organization and settlement' that was best understood through its relationships with - and similarity to - other global cities rather than to its home country or immediate neighbors', according to S. Rajaratnam, one of Singapore's early leaders and most famous ideologues (Rajaratnam, 2007). The same logic of strong outward orientation translates into research and education. Just as former British trading had attracted a range of regional headquarters by multinational companies as a form of insurance policy to make Singapore's survival the interest of a globalizing economy, so initiatives like SMA, SMART, and SUTD serve as a way to force prominent international institutions like MIT to have 'skin in the game in Singapore's future', a senior policy-maker remarked. At the same time, internationalization in education was imperative for Singapore's envisaged development. A senior policy maker explains: 'We recognized we are a small economy ... starting from far behind the curve compared to other countries. And recognized ourselves that we would have to be very open and very international about, you know, research and innovation policy.'

Finally, national enhancement through the import of foreign models betrays yet another 'revealing trait regarding Singapore as a nation: [its] obsession with similes' (Choon, 2004). The different generations of the 'MIT model' fit into a lineage of shifting identity politics of a young, hybrid, multi-ethnic, and decidedly modernist country that keeps narrating its own status as a 'tabula rasa' through new analogies (Lim, 2004). These reinventions range from a focus on ethnicity and security during the early days of nationhood ('Lion City', 'Malaysian Malaysia', 'Swiss style of living', the 'Hedgehog', or the 'Poisoned Shrimp') to more recent techno-spatial forms of identity ('Garden city', 'Global City',' 'Intelligent Island', 'Biopolis'), which the MIT partnerships both drew upon and reinforced. 


\section{From panacea to diagnosis: Imaginaries of innovation in three political cultures}

These three case studies demonstrate how the actors in the UK, Portugal, and Singapore envisioned fundamentally different futures when seeking to foster innovation with the help of MIT. Each partnership, we have argued, drew on a different understanding of why innovation was needed, what the perceived national weakness or deficiencies the 'MIT model' could treat, and which social and institutional changes were acceptable in this context. The different imaginaries of innovation underwriting our cases are perhaps most succinctly captured in the different names of the partnerships: a joint research institute between two equal institutions (the Cambridge-MIT Institute); a network that links MIT to an entire country (the MIT-Portugal Program); and the enrolment in a global alliance (the Singapore-MIT Alliance). Table 2 summarizes the imaginaries of innovation and their relationships to MIT (Table 1).

In Cambridge, the push for innovation was informed by a felt need for rejuvenation to retain global economic and scientific leadership. It was envisioned as a targeted, localized injection of MIT's innovation capability into an existing strong university, informed by an understanding that this perceived national crisis could be addressed only through one of the country's preeminent academic institutions and the hope that the cure would diffuse from Cambridge through the entire system. CMI represents a quasi-linear model of innovation where the front end of the innovation pipeline - fundamental research was considered well established and the industry counterparts were seen as strong but disconnected. Innovation in Portugal, by contrast, was imagined as an external aid, or prosthetic to overcome a self-inflicted crippling and to catch up with other countries whose development Portugal had once helped spark. MPP had to take into account Portugal's shocks of decolonization and post-dictatorship democratization, and a subsequent image as a 'delayed,' 'catching-up' country, suffering from self-inflicted ills. Portugal's historical experience called for a less elitist, more societally consensual multiinstitutional approach and a more decisive import of foreign practices breaking with existing institutional traditions.

Innovation in Singapore was one vehicle among several to compensate for size and security disadvantages through global economic ties, technological leadership, and 'personal' investments by foreigners (such as MIT researchers) in Singapore's future. SMA, SMART and SUTD firmly reify Singapore's decades-long striving for integration into global economic and security networks, reflecting a long-standing fear of geopolitical, economic, and identity loss. Enacted through a pattern of constant adaptation to changing outward conditions, the three initiatives represent an imaginary of innovation as enhancement - a constant augmentation of the body by the latest available therapeutic technologies, in conjunction with continual monitoring and careful, iterative treatment planning. Innovation via MIT was envisioned as a functionally and temporally disaggregable set of enhancement activities, implemented in sequenced fashion that paralleled shifts in governmental development priorities, such as the transition from an efficiency to a creativity-driven economy and from a self-image as 'intelligent island' to 'Biopolis'.

Where do these cases this leave us with regard to current innovation theory and policy practice? To begin with, our analysis complicates the common notion that innovation can 


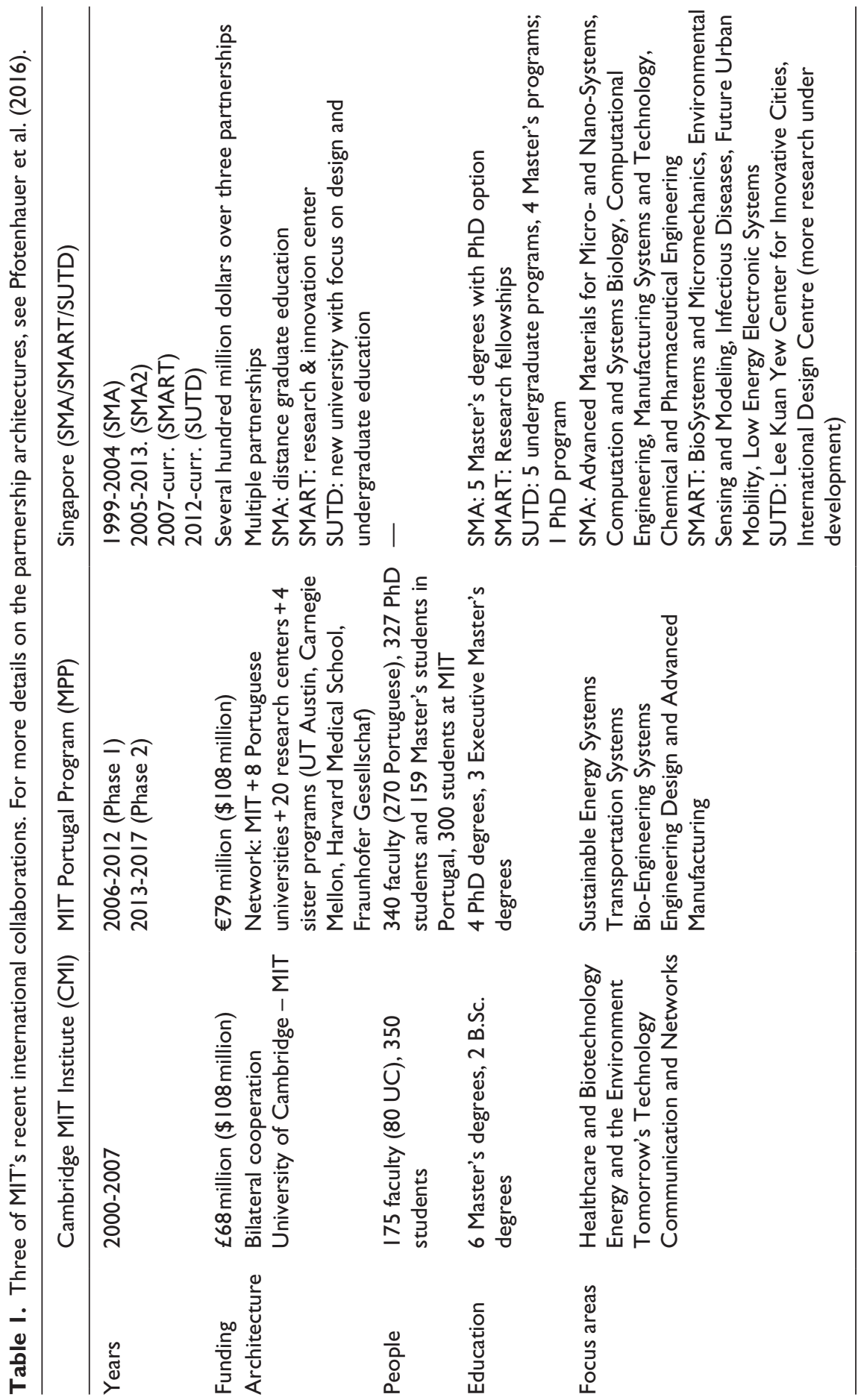




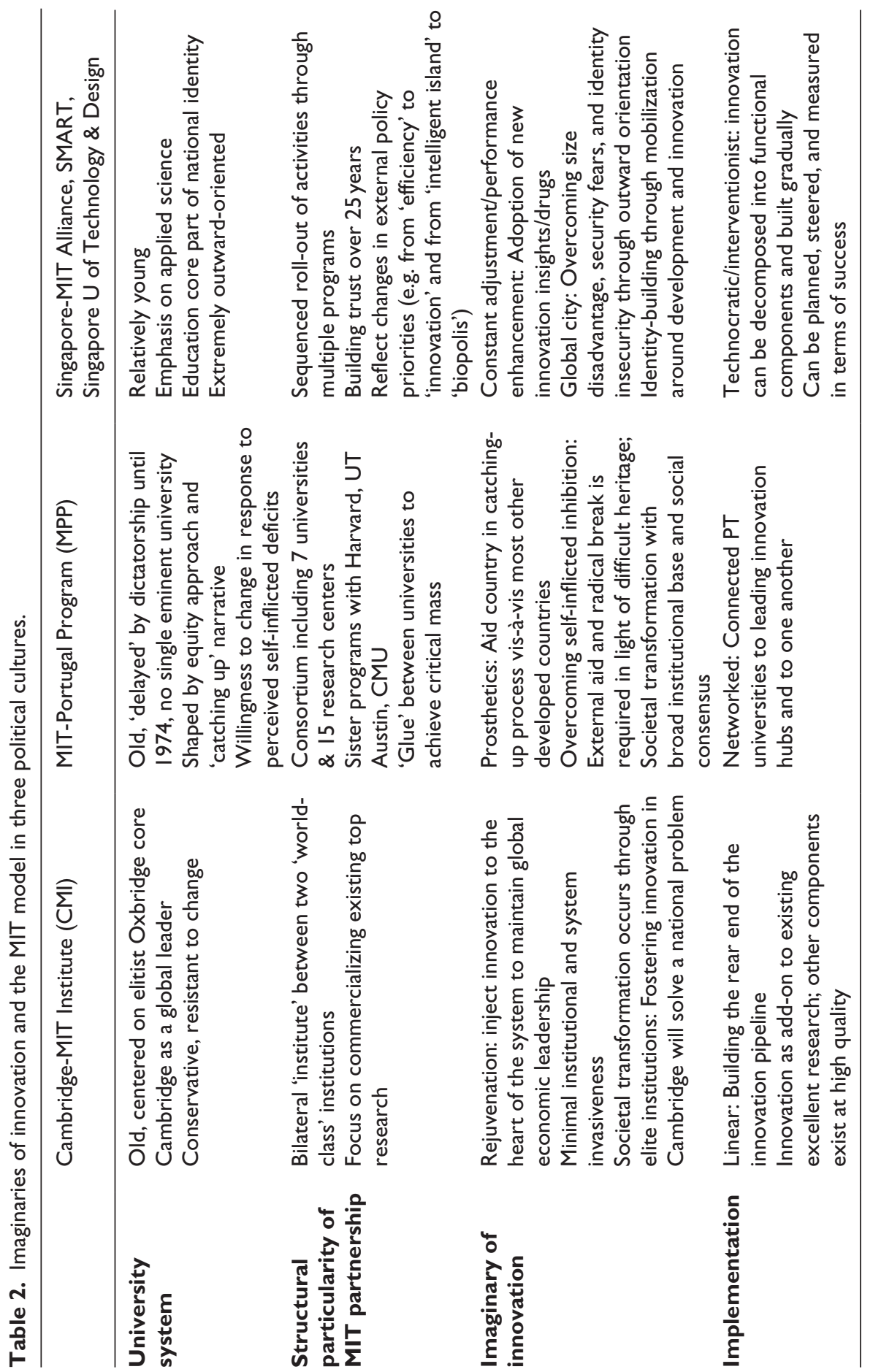


be easily captured through 'models' (Godin, 2015b). It thus responds to the growing discomfort with the universalist assumptions underwriting the development and circulation of 'innovation models' as seen in empirical studies that have trouble reconciling the static and structural notions of innovation pipelines, systems, helices or universal 'best practices' with the dynamic cultural and political particularities of the diverse regions they are supposed to fix. While these critiques have emerged mostly in developing country contexts, our study shows that even among relatively 'developed' countries the idea of a universal set of innovation mechanics and rationales does not hold true. A fortiori, the same can be said even more forcefully for less developed countries. Contrary to most studies concerned with innovation models, this lack of unity is not simply a matter of 'degree of development', where some countries or institutions are 'not ready for' effective innovation, or where a model fails to take hold because the context is ill-suited. Blatant discrepancies between idealized models and their practical implementation, or best-practice sources and emulations of them, cannot be reduced by improving on existing models, nor can a single theory of innovation ever encompass innovation in all contexts. Instead, a more radical shift is needed in the 'science of innovation policy' to explain, and work with, the differences observed here.

Second, our study provides some conceptual inroads for treating innovation more seriously as a locally constructed concept. As shown above, innovation cannot be theorized as a scheme in which social, political and cultural factors are simply factors that add to or detract from the success of prescribed routines. Innovation models are not sets of practices that travel unchanged across social, cultural, and jurisdictional boundaries. Rather, they are responses to local imaginaries that reflect countries' prior conceptions of, and justifications for, the need for innovation, and which systems or components they therefore involve in its implementation. The 'MIT model' sought and imported by the three countries neither existed outside the specific imagination of MIT's partners, nor preceded the partnerships in time. ${ }^{8}$ Imaginaries of innovation, we submit, thus provide an entry point for a constructivist, locally grounded theory of innovation policy while still recognizing innovation's global reference points and entanglements. Just as STS research has recognized multiple publics over a singular public (Jasanoff, 2005a; Wynne, 1992), we can make a habit of speaking about innovation not as a unified concept, but as a plurality of imaginaries of innovation.

Third, by extension, our analysis suggests that current policy initiatives, including the three MIT partnerships, tend to get their logic backwards: That is, they tend to ask first what innovation is, and then, equipped with a conceptual blueprint, to try to reconcile this model with local needs and socio-cultural particularities. Opposing this view, we suggest that policy-makers might be better served by first determining as precisely as possible the deficiencies they seek to address through innovation, the constituencies that share or oppose their deficit diagnosis and complementary vision of a desirable future, and the accessible political, social, and institutional pathways for attaining them. This, in turn, would enable them to articulate better why they are turning to foreign advice or certain theories in the first place, what precisely they are seeking from a given model, and why only certain 'models' are deemed feasible in their specific local context.

Fourth, a constructivist theory of innovation also provides a better explanation for what we commonly call 'successes' or 'failures' in policy initiatives. Common wisdom holds 
that failure occurs if the context is too alien to allow countries to conform to the preconditions that make the innovation model work. Conversely, success is typically ascribed to the successful implementation of a model in a given context. Our findings suggest that questions as to why certain models 'take' or 'fail' should better be re-stated in terms of how effectively a society has been able to articulate the epistemic and normative foundations for rationalizing and enhancing its own future through innovation. CMI was considered a partial failure by many, arguably because it did not manage to connect the government's diagnosis of university-owed economic decline and its associated vision of national transformation through an overhaul of a prestigious academic institution to the goals and self-imagination of Cambridge itself. In contrast, MPP was considered a success, leading to a renewal of the partnership even in dire economic times, partly because it fulfilled the desire for externally induced change by way of an internationally recognized brand that could put Portugal on the global map. Singapore, finally, saw much of the value of the partnership in the continued presence of a foreign partner that could further the need for cutting-edge 'best practices.' In each case, 'success' has principally to do with being able to explicate existing sociotechnical imaginaries and counter-imaginaries that shape the very need for, and conceptualization of, innovation - and hence what counts as 'success' and 'failure' in the first place. It puts the burden of proof up-front on the government seeking innovation, not on the model deemed to be a cure for all ailments.

Fifth, the medical metaphor provides useful means for articulating some of the tacit or unspecified reasons why innovation is sought and the idiosyncratic differences among different innovation cultures. It allows us to point to different diagnoses of social ills, their prescribed cures, and reactions to the cure by the host metabolism. We saw that the diagnosis of the problem - a loss of leadership in the UK, a self-inflicted lag in Portugal, and a size disadvantage in Singapore - matters to the construction of innovation as a solution. Likewise, this diagnosis determined what MIT stood for as a cure to be accommodated within the respective political cultures - a minimally invasive injection in the UK, an external aid to overcome broken structures in Portugal, and enhancement of extant strengths in Singapore.

The medical language also helps us to tackle the misleading 'panacea' rhetoric surrounding innovation in current policy discourse, manifest in the circulation of models and best practices. The nature of the 'disease' does matter to the local conception of innovation; the incorporation of a presumably standardized innovation model does not result in uniform prescriptions across all contexts, and may indeed trigger variegated and usually complex reactions within a body politic, including rejection. In this paper, we use the presumed universality of innovation models as a diagnostic probe that reveals implicit diagnoses of social deficiency, visions of a better future, and the normatively distinct pathways taken in search for recovery. We believe that it would be productive for policymakers and other actors involved in innovation policy to make these implicit diagnoses publicly explicit. Incidentally, this might also help establish 'innovation' as a political category and the 'innovation state' as a political state, subject to processes of democratic representation, participation, and accountability (Pfotenhauer and Juhl, 2017). From a constructivist perspective, it might be more desirable to speak of innovation at the macro-scale as 'innovation cultures', rather than 'systems', which is compatible with our analysis of different imaginaries of innovation. 
Finally, our study underlines the role of power differentials in the global political economy of innovation. In all three cases, policy-makers turned to one particular source, a university located in the United States, to find a trusted cure for their situated social challenges. At a time when extensive social and institutional reconfigurations are regularly being justified in the name of innovation, such concentrated authority over what innovation ought to look like has important consequences for democratic and fiscal accountability. In fact, in at least two of our cases, reference to MIT's external authority arguably allowed the importing authorities to circumvent some of the political opposition to enact structural reforms that might otherwise have received little support - increased national collaboration in Portugal and the creation of an additional engineering university in Singapore (Pfotenhauer et al., 2013, 2016). Models like 'MIT' or 'Silicon Valley' thus act as common reference points for a global community of innovation practitioners and policy makers who authorize practices and imagine their circulation in places as geographically dispersed as the UK, Portugal, and Singapore. In this logic, to become an innovative institution or region is to compete within frames of reference set by innovation leaders such as the United States, and, specifically in our cases, to accept MIT as a shared reference point - those not able to recreate MITs or the like on their own soil are de facto not competing in innovation as collectively imagined. Our study is therefore representative of a global political economy of innovation in which a small number of actors who can credibly claim insider knowledge of 'best practices' wield disproportionate power.

In conclusion, future research might seek to investigate how various imaginaries of innovation - whether tied to different local constituencies or to different best-practice models - may compete with one another, or how the circulation of models of practice feeds back into the redefinition of each model at its site of origin. Tentative research in this direction suggests that MIT's international educational and research experiences over decades, and particularly its close ties to Singapore, have had considerable impact on the Institute's self-imagination and strategic orientation. Traveling imaginaries of innovation, in short, are two-edged: They affect not only the recipients' diagnosis of social ills, but also the purveyors' sense of the possibilities of therapy.

\section{Acknowledgements}

The authors would like to thank the many informants and interviewees in the U.S., the U.K., Portugal, and Singapore who made this study possible, as well as four anonymous reviewers for their constructive criticism.

\section{Funding}

This work was supported by the NSF Science of Science and Innovation Policy (SciSIP) Program under Collaborative Grant No. 1262263 'Technology, Collaboration, Learning: Modeling Complex International Innovation Partnerships' (Sebastian Pfotenhauer) and the NSF Science, Technology and Society (STS) Program under Grant No. 1457011 'Traveling Imaginaries of Innovation.'

\section{Notes}

1. The historical succession of various innovation models tends to be conveniently narrated as a stringent theoretical evolution, obscuring complex origins and the normative implications of theorizing innovation in one way rather than another (Godin, 2015b). In particular, these 
models have retained a core commitment to explain innovation as something that happens between apolitical technologies and apolitical markets, thus consistently sidelining a deeper normative engagement with society, culture and state politics (Pfotenhauer and Juhl, 2017).

2. Notions of culture in innovation policy frequently assume that there is a single 'right' culture for innovation. For example, the OECD, an international policy organization with a specifically comparative agenda, suggests in its 2010 Innovation Strategy that 'building a culture of innovation is essential', ignoring the social norms, political structures, and historical experience that underwrite cultures. At times, differences in culture are equated with macro-economic indicators, that is, 'factors such as a country's economic structure, its firm demography (e.g. number of SMEs), its geography and resource endowment, its infrastructure, stage of socioeconomic development, and institutional environment (e.g. the education system and science and research base)' (OECD, 2010). This is consistent with the largely structural approaches towards differentiation in the innovation systems literature. For example, Edquist (2005) suggests that a national system of innovation includes 'all important economic, social, political, organizational, institutional and other factors that influence the development, diffusion and use of innovation'; yet he concedes that 'we do not know the determinants of innovation systematically and in detail'. In her popular book The Entrepreneurial State, Mazzucato (2015) theorizes the state primarily as an economic actor capable of fueling "the dynamics of capitalism [through] the most courageous, early and capital intensive "entrepreneurial" investments'. Rarely does Mazzucato's 'state' reveal other properties, such as social, political and cultural ones, let alone considerations of cross-national difference. Regional innovation studies, spearheaded by Saxenian's (1996) classic 'regional advantage', tend to fare somewhat better and focus explicitly on organizational culture, but still do not address questions of social identity, collective self-imagination, or political culture.

3. Our paper uses as its primary data source more than 100 semi-structured interviews with actors involved in the three MIT collaborations (both on the MIT and the partner side) carried out between 2011 and 2014, including with faculty, students, policy-makers, program managers and representatives of third-party institutions. On the MIT side, many of the key actors have been involved in more than one partnership. All findings have been cross-validated through iterative rounds of interviews and triangulation of information from various sources. The paper further builds broad document research both of publicly accessible and non-public MIT-internal documents, and part-time participant observation in one of MIT's international partnerships.

4. Sociotechnical imaginaries do not necessarily operate at the national scale, nor do they depend on a singular understanding of culture (Jasanoff, 2015). Collectively held imaginaries may be articulated or propagated by sub- or trans-national level communities, and they evolve over time. They may emanate from 'vanguard visions' of individuals or small groups (Hilgartner, 2015). Likewise, imaginaries may be contested, and competing imaginaries can exist in parallel in relation to major sociotechnical developments. Examples such as the recent 'Brexit' vote in the United Kingdom illustrate that incompatible visions of Britain's future coexisted for quite some time, and those public self-imaginations did not necessarily coincide with the mainstream government vision. Choosing the appropriate unit of analysis and the axis of comparison (e.g. cross-national differences or intra-national competing imaginaries) may thus cast light on different sets of research questions.

5. Somewhat unexpectedly, the education activities, and particularly the undergraduate exchange, outlived the research activities, even though many of them were tagged on at the last minute. Initially, it was not clear whether undergraduate education should be part of the partnership at all. MIT considered undergraduate education essential for instilling innovativeness at the earliest stage, in quasi-embryonic form, in the university community. In contrast, 
the UK government considered undergraduate activities not essential to CMI's mission of innovation and a form of 'double-dipping' for education from UK government. Yet the CMI undergraduate exchange program went on to become one of the 'signature achievements' of the partnership.

6. One could also see CMI's struggle as the result of two competing sociotechnical imaginaries - a national one, propagated by Gordon Brown and other policy-makers, about the role of universities for the national economy and the type of university needed to fix a national problem; and an institutional one about the role and identity of Britain's oldest university.

7. Ironically, these recommendations were never fully implemented at MIT. Yet, the institutionwide initiative for an educational overhaul together with an ever-growing focus on design had sparked significant interest among faculty, many of whom were involved in the Singapore initiative. In fact, some faculty were willing to engage in SUTD precisely as a form of educational experiment to try out some of the practices originally contemplated for MIT.

8. This emphasis on cultural contingency is consistent with work by Godin (2015a, 2015b) who has traced the construction of innovation models over in different periods of time.

\section{References}

Acemoglu D, Johnson S and Robinson JA (2002) Reversal of fortune: Geography and institutions in the making of the modern world income distribution. The Quarterly Journal of Economics 117(4): 1231-1294.

African Union (2014) African Union heads of state and government adopt the science, technology and innovation strategy for Africa. Available at: https://au.int/en/newsevents/27635/africanunion-heads-state-and-government-adopt-science-technology-and-innovation (accessed 24 July 2014).

Aiginger K (2004) The bumpy road of convergence: The catching up experience in Portugal, Spain and Greece. Estudios de Economia Aplicada 22(3): 451-473.

Alberta Government (2014) Alberta aims innovation at economic development. Available at: http://alberta.ca/release.cfm?xid=36844b6a86a87-daee-002f-40b0def82171f94f $\quad$ (accessed 24 July 2014).

Amsden AH (2007) Escape from Empire: The Developing World's Journey through Heaven and Hell. Cambridge, MA: The MIT Press.

Anderson B (1991) Imagined Communities: Reflections on the Origin and Spread of Nationalism. London: Verso.

Appadurai A (1996) Modernity at Large: Cultural Dimensions in Globalization. Minneapolis, MN: University of Minnesota Press.

Arocena R and Sutz J (2000) Looking at national systems of innovation from the South. Industry and Innovation 7(1): 55-75.

Barben D, Fisher E, Selin C, et al. (2007) Anticipatory governance of nanotechnology: Foresight, engagement, and integration. In: Hackett EJ, Amsterdamska O, Lynch ME,et al. (eds) The Handbook of Science and Technology Studies. Cambridge, MA: The MIT Press, 979-1000.

Barro RJ and Sala-i-Martin X (1992) Convergence. Journal of Political Economy 100(2): 223-251. Beck U (1992) Risk Society: Towards a New Modernity. London: SAGE.

Borup M, Brown N, Konrad K, et al. (2006) The sociology of expectations in science and technology. Technology Analysis \& Strategic Management 18(3-4): 285-298.

Braczyk H-J, Cooke P and Heidenreich M (2004) Regional Innovation Systems: The Role of Governances in a Globalized World. London: Routledge.

Bresnahan T and Gambardella A (2004) Building High-Tech Clusters: Silicon Valley and beyond. Cambridge: Cambridge University Press. 
Brickman R, Jasanoff S and Ilgen T (1985) Controlling Chemicals: The Politics of Regulation in Europe and the United States. Ithaca, NY: Cornell University Press.

Bush V (1945) Science, the Endless Frontier. Washington, DC: Office of Scientific Research and Development.

Callaghan Innovation (2014) Statement of Intent 2014-2018: Callaghan Innovation accelerates commercialisation of innovation by firms in New Zealand. Available at: https://www. callaghaninnovation.govt.nz/sites/all/files/sites/all/files/pictures/Callaghan_SOI-Jun14.pdf (accessed 12 November 2014).

Cambridge-MIT Institute (CMI) (2005) Cambridge MIT Institute annual report, 2005. Available at: http://web.mit.edu/annualreports/pres05/13.01.pdf (accessed 1 April 2011).

Cambridge-MIT Institute (CMI) (2008) Accelerating Innovation by Crossing Boundaries: The Cambridge MIT Institute 2000-2006. Cambridge, MA: Massachusetts Institute of Technology.

Casper S (2007) Creating Silicon Valley in Europe: Public Policy towards New Technology Industries. Oxford: Oxford University Press.

Cassiolato JE and Vitorino V (2011) BRICS and Development Alternatives. London: Anthem Press.

Chaminade C and Padilla Pé rez R (2014) The challenge of alignment and barriers for the design and implementation of science, technology and innovation policies for innovation systems in developing countries. Lund University, CIRCLE Center for Innovation, Research and Competences in the Learning Economy. Available at: https://ideas.repec.org/p/hhs/ lucirc/2014_026.html (accessed 17 February 2017).

Choon BK (2004) Narrating imagination. In: Choon BK, Pakir A and Kiong TC (eds) Imagining Singapore. Singapore: Eastern Universities Press, 1-15.

Chuan Poh L (2010) Singapore: Betting on biomedical sciences. Issues in Science and Technology 26(3): 69-74.

Clancey G (2012) Intelligent Island to biopolis: Smart minds, sick bodies and millennial turns in Singapore. Science, Technology and Society 17(1): 13-35.

Conceição P, Heitor M and Veloso F (2003) Infrastructures, incentives, and institutions: Fostering distributed knowledge bases for the learning society. Technological Forecasting and Social Change 70(7): 583-617.

De Ferranti D, Perry GE, Gill I, et al. (2003) Closing the Gap in Education and Technology. Washington, DC: The World Bank.

De Sousa Santos B (2009) Portugal: Tales of being and not being. Portuguese Literary and Cultural Studies 20: 1-46.

Dearing R (1998) Higher Education in the Learning Society: Report of the National Committee of Inquiry into Higher Education (Dearing report). London: Stationery Office.

Deem R, Hillyard S and Reed M (2007) Knowledge, Higher Education, and the New Managerialism: The Changing Management of UK Universities. Oxford: Oxford University Press.

Department of Trade and Industry (DTI) (2001) UK innovation performance: Strengths, weaknesses, opportunities, threats and main problems. UK Department of Trade and Industry. Available at: http://ukandeu.ac.uk/wp-content/uploads/2016/06/SWOTS.pdf (accessed 16 February 2017).

Dryzek JS (1990) Discursive Democracy: Politics, Policy, and Political Science. Cambridge: Cambridge University Press.

Dutrénit G and Puchet M (2017) Tensions of STI policy in Mexico: Analytical models, institutional evolution, national capabilities and governance. In: Kuhlmann $\mathrm{S}$ and Ordóñez-Matamoros G (eds) International Research Handbook on Science, Technology and Innovation Policy in Developing Countries: Rationales and Relevance. Cheltenham: Edward Elgar Publishing, 205-231. 
Edquist C (2005) Systems of innovation: Perspectives and challenges. In: Fagerberg J, Mowery DC and Nelson R (eds) The Oxford Handbook of Innovation. Oxford: Oxford University Press, 181-208.

Elejalde-Ruiz A (2014) Panel OKs Fulton market innovation district. The Chicago Tribune, 18 July.

Etzkowitz H (2002) MIT and the Rise of Entrepreneurial Science. New York: Routledge.

Etzkowitz H (2008) The Triple Helix: Industry, University, and Government in Innovation. New York: Routledge.

European Commission (2014) RIS3 Peer Review Workshop, Dublin, 3-4 July. Available at: http://s3platform.jrc.ec.europa.eu/documents/20182/89527/Ireland_Feedback_xReport_ Peer_Review_Sept2014_final.pdf/ba857a5c-fb32-47b8-a703-fc25880b3255

European Council (2000) Conclusions of the Presidencys (Lisbon Strategy). Lisbon European Council. Available at: http://www.europarl.europa.eu/summits/lis1_en.htm (accessed 17 February 2017).

Fagerberg J, Martin BR and Andersen ES (2013) Innovation Studies: Evolution and Future Challenges. Oxford: Oxford University Press.

Fagerberg J, Mowery DC and Nelson RR (2006) The Oxford Handbook of Innovation. Oxford: Oxford University Press.

Feldman MP (1994) The Geography of Innovation. New York: Springer Science \& Business Media.

Florida R (2005) The world is spiky. The Atlantic, October, 48-51.

Godin B (2006) The linear model of innovation: The historical construction of an analytical framework. Science, Technology \& Human Values 31(6): 639-667.

Godin B (2014) 'Innovation Studies': Staking the claim for a new disciplinary 'tribe'. Minerva 52(4): 489-495.

Godin B (2015a) Innovation Contested: The Idea of Innovation over the Centuries. London: Routledge.

Godin B (2015b) Models of innovation: Why models of innovation are models, or what work is being done in calling them models? Social Studies of Science 45(4): 570-596.

Godin B and Lane JP (2013) Pushes and pulls: Hi(S)tory of the demand pull model of innovation. Science, Technology \& Human Values 38(6): 621-654.

Guston DH (2008) Innovation policy: Not just a jumbo shrimp. Nature 454: 940-941.

Heitor M and Bravo M (2010) Portugal at the crossroads of change, facing the shock of the new: People, knowledge and ideas fostering the social fabric to facilitate the concentration of knowledge integrated communities. Technological Forecasting and Social Change 77(2): $218-247$.

Heitor M and Horta H (2011) Science and technology in Portugal: From late awakening to the challenge of knowledge-integrated communities. In: Neave G and Amaral A (eds) Higher Education in Portugal 1974-2009. Dordrecht: Springer, 179-226.

Hilgartner S (2015) Capturing the imaginary: Vanguards, visions and the synthetic biology revolution. In: Jasanoff S and Kim S-H (eds) Dreamscapes of Modernity: Sociotechnical Imaginaries and the Fabrication of Power. Chicago, IL: University of Chicago Press, 33-55.

Huff WG (1995) The developmental state, government, and Singapore's economic development since 1960. World Development 23(8): 1421-1438.

Islam N (2003) What have we learnt from the convergence debate? Journal of Economic Surveys 17(3): 309-362.

Jasanoff S (2001) Image and imagination: The formation of global environmental consciousness. In: Miller CA and Edwards PN (eds) Changing the Atmosphere: Expert Knowledge and Environmental Governance. Cambridge, MA: MIT Press, 309-337. 
Jasanoff S (2004) States of Knowledge: The Co-Production of Science and the Social Order. London: Routledge.

Jasanoff S (2005a) Chapter 10: Civic epistemology. In: Jasanoff S Designs on Nature: Science and Democracy in Europe and the United States. Princeton, NJ: Princeton University Press, 247-271.

Jasanoff S (2005b) Designs on Nature: Science and Democracy in Europe and the United States. Princeton, NJ: Princeton University Press.

Jasanoff S (2015) Future imperfect: Science, technology, and the imaginations of modernity. In: Jasanoff S and Kim S-H (eds) Dreamscapes of Modernity: Sociotechnical Imaginaries and the Fabrication of Power. Chicago, IL: University of Chicago Press, 1-47.

Jasanoff S and Kim S-H (2009) Containing the atom: Sociotechnical imaginaries and nuclear power in the United States and South Korea. Minerva 47(2): 119-146.

Jasanoff S and Kim S-H (eds) (2015) Dreamscapes of Modernity: Sociotechnical Imaginaries and the Fabrication of Power. Chicago, IL: University of Chicago Press.

Keeling R (2006) The Bologna process and the Lisbon research agenda: The European Commission's expanding role in higher education discourse. European Journal of Education 41(2): 203-223.

Keen Meng C (2010) Singapore's changing economic model. In: Chong T (ed.) Management of Success: Singapore Revisited. Singapore: Institute of Southeast Asian Studies, 123-138.

Kelman S and Wilson JQ (1981) Regulating America, Regulating Sweden: A Comparative Study of Occupational Safety and Health Policy. Cambridge, MA: The MIT Press.

Kenney M (2000) Understanding Silicon Valley: The Anatomy of an Entrepreneurial Region. Palo Alto, CA: Stanford University Press.

Kline SJ and Rosenberg N (1986) An overview of innovation. In: Rosenberg N and Landau A (eds) The Positive Sum Strategy: Harnessing Technology for Economic Growth. Washington, DC: The National Academy Press, 275-305.

Kuhlmann S and Ordóñez-Matamoros G (2017) Governance of innovation in emerging countries: Understanding failures and exploring options. In: Kuhlmann S and Ordoñez-Matamoros G (eds) Research Handbook on Innovation Governance for Emerging Economies: Towards Better Models. Northampton, MA: Edward Elgar Publishing, 1-36.

Kuhlmann S, Shapira P and Smits R (2012) A systemic perspective: The innovation policy dance. In: Smits R, Kuhlmann S and Shapira P (eds) The Theory and Practice of Innovation Policy: An International Research Handbook. Cheltenham: Edward Elgar Publishing, 1-22.

Lains P (2003) Catching up to the European core: Portuguese economic growth, 1910-1990. Explorations in Economic History 40(4): 369-386.

Latour B (1993) We Have Never Been Modern. Cambridge, MA: Harvard University Press.

Lee C-M, Miller W, Rowen H, et al. (2000) The Silicon Valley Edge: A Habitat for Innovation and Entrepreneurship. Stanford, CA: Stanford University Press.

Lim WSW (2004) Architecture, Art, Identity in Singapore: Is There Life after Tabula Rasa? Singapore: Asian Urban Lab.

Lundvall B-A (1992) National Innovation Systems: Towards a Theory of Innovation and Interactive Learning. London: Pinter.

Lundvall B-Å, Joseph KJ, Chaminade C, et al. (2010) Handbook of Innovation Systems and Developing Countries: Building Domestic Capabilities in a Global Setting. Cheltenham: Edward Elgar Publishing.

Malerba F (2005) Sectoral systems of innovation: A framework for linking innovation to the knowledge base, structure and dynamics of sectors. Economics of Innovation and New Technology 14(1-2): 63-82. 
Massachusetts Institute of Technology (MIT) (2005) Program overview brochure, MIT Portugal Program. Available at: http://www.mitportugal.org/about/documents/general/3-mit-portugalprogram-main-brochure/file (accessed 17 February 2017).

Mazzucato M (2015) The Entrepreneurial State: Debunking Public vs. Private Sector Myths, revised edn. Philadelphia, PA: PublicAffairs.

Nelson R (1993) National Innovation Systems: A Comparative Analysis. Oxford: Oxford University Press.

Nowotny H (2006) The quest for innovation and cultures of technology. In: Nowotny H (ed.) Cultures of Technology and the Quest for Innovation. New York: Berghahn Books, 1-26.

Office of Science and Technology Policy (OSTP) (2014) Strategy for American innovation: Notice of request for information. Available at: https:/www.federalregister.gov/articles/2014/07/29/2014-17761/strategy-for-american-innovation (accessed 17 February 2017).

Organization for Economic Cooperation and Development (OECD) (1997) National innovation systems. Available at: https://www.oecd.org/science/inno/2101733.pdf (accessed 17 February 2017).

Organization for Economic Cooperation and Development (OECD) (2010) The OECD innovation strategy. Available at: http://www.oecd.org/sti/the-oecd-innovation-strategy9789264083479-en.htm (accessed 17 February 2017).

Papaioannou T, Rush H and Bessant J (2006) Benchmarking as a policy-making tool: From the private sector to the public sector. Science and Public Policy 33(2): 91-102.

Perry M, Kong L and Yeoh BSA (1997) Singapore: A Developmental City State. Hoboken, NJ: Wiley.

Pfotenhauer SM (in press) Can innovative universities be made? 'Best-practice transfer' and the globalizing 'MIT model'. In: Wisnioski M, Hintz E and Stettler M (eds) Can Innovators Be Made?

Pfotenhauer SM and Jasanoff S (2017) Traveling imaginaries: The 'practice turn' in innovation policy and the global circulation of innovation models. In: Tyfield D, Randalls S, Lave R, et al. (eds) The Routledge Handbook of the Political Economy of Science. London: Routledge, 416-428.

Pfotenhauer SM and Juhl J (2017) Innovation and the political state: Beyond the myth of technologies and markets. In: Godin B and Vinck D (eds) Reflexive Innovation: Alternative Approaches to the Pro-Innovation Bias. Cheltenham: Edward Elgar Publishing.

Pfotenhauer SM, Jacobs JS, Pertuze J, et al. (2013) Seeding change through international university partnerships: The MIT-Portugal Program as a driver of internationalization, networking, and innovation. Higher Education Policy 26(2): 217-242.

Pfotenhauer S, Wood D, Roos D, et al. (2016) Architecting complex international science, technology and innovation partnerships (CISTIPs): A study of four global MIT collaborations. Technological Forecasting and Social Change 104: 38-56.

Rajaratnam S (2007) Singapore: Global city. In: Chee CH and Ul Haq O (eds) S. Rajaratnam: The Prophetic and the Political. Singapore: Institute of Southeast Asian Studies, 225-227.

Remaking Singapore Committee (2003) Changing mindsets, deepening relationships: The report of the Remaking Singapore Committee. Available at: http://eresources.nlb.gov.sg/webarchives/ details/www.remakingsingapore.gov.sg.html (accessed 17 February 2017).

Royal Society (2014) Submission to the Government's science and innovation strategy. Available at: https://royalsociety.org/policy/publications/2014/submission-on-science-innovation-strategy/ (accessed 17 February 2017).

Saxenian A (1996) Regional Advantage: Culture and Competition in Silicon Valley and Route 128. Cambridge, MA: Harvard University Press. 
Schön DA and Rein M (1995) Frame Reflection: Toward the Resolution of Intractrable Policy Controversies. New York: Basic Books.

Simmonds P, Stroyan J and Clark J (2009) An evaluation of the Cambridge-MIT Institute. Technopolis Group 2. Available at: http://www.siampi.eu/24/smartsite.dws@lang=ENG\&c $\mathrm{h}=$ SIA\&id=25490\&pubid=27.html

Singapore University of Technology and Design (SUTD) (2012) SUTD President's Message. Available at: http://sutd.edu.sg/About-Us/News-and-Events/Press-Releases/2012/5/Speechby-SUTD-President,-Professor-Thomas-Magnant (accessed 30 March 2017).

Singapore-MIT Alliance (SMA) (2005) SMA homepage - Prospective students. Available at: http://web.mit.edu/sma/students/programmes/cpe.htm (accessed 17 February 2017).

Stone D (2001) Policy Paradox: The Art of Political Decision Making. New York: W. W. Norton \& Company.

Sturken M, Thomas D and Ball-Rokeach S (2004) Technological Visions: Hopes and Fears That Shape New Technologies. Philadelphia, PA: Temple University Press.

Tan K-S and Phang S-Y (2005) From Efficiency-Driven to Innovation-Driven Economic Growth: Perspectives from Singapore. Washington, DC: World Bank Publications. Available at: http:// elibrary.worldbank.org/doi/abs/10.1596/1813-9450-3569 (accessed 17 February 2017).

Taylor C (2003) Modern Social Imaginaries. Durham, NC: Duke University Press.

Timmermans S and Berg M (1997) Standardization in action: Achieving local universality through medical protocols. Social Studies of Science 27(2): 273-305.

Tufts University (2014) Launch of the Tufts Institute for Innovation. Available at: http://president. tufts.edu/2014/07/launch-of-the-tufts-institute-for-innovation-august-28-2014/ (accessed 17 February 2017).

University of Cambridge (1999a) Cambridge and MIT: Torchbearers to UK's enterprise future. Available at: http://web.mit.edu/cmi/media/pr-1999110801.html (accessed 30 March 2017).

University of Cambridge (1999b) Cambridge-MIT partnership launched. Available at: http:// www.cam.ac.uk/news/cambridge-mit-partnership-launched (accessed 17 February 2017).

Veugelers R and Mrak M (2009) The knowledge economy and catching-up member states of the European Union. >European Commission. Available at: http://ec.europa.eu/invest-inresearch/pdf/download_en/kfg_report_no5.pdf (accessed 17 February 2017).

Wong P-K (1995) Singapore's technology strategy. In: Simon DF (ed.) The Emerging Technological Trajectory of the Pacific Rim. New York: M.E. Sharpe, 103-131.

Wynne B (1992) Misunderstood misunderstanding: Social identities and public uptake of science. Public Understanding of Science 1(3): 281-304.

\section{Author biographies}

Sebastian Pfotenhauer is an Assistant Professor at the Munich Center for Technology in Society (MCTS) and the TUM School of Management at Technical University Munich. At MCTS, he heads the research group Innovation, Society and Public Policy. His research interests include regional innovation cultures as well as science and technology in international settings. He previously was a research scientist and lecturer with the MIT Technology \& Policy Program and a Fellow at the Harvard Program on Science, Technology, and Society.

Sheila Jasanoff is Pforzheimer Professor of Science and Technology Studies (STS) at the Harvard Kennedy School, where she founded and directs the Program on Science, Technology and Society. Formerly she was founding chair of the STS department at Cornell. Her research centers on the production and use of expert knowledge in legal and political decision-making in comparative and global contexts. Her books include The Fifth Branch, Science at the Bar, Designs on Nature, and The Ethics of Invention. 